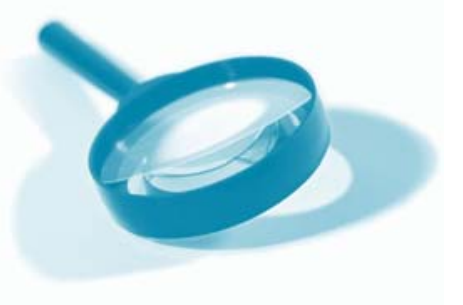

\title{
Lea ming chemistry through placements: building on good practice and identifying new opportunities
}

\author{
Simon T Belt* and \\ Elizabeth M Vincent \\ Centre for Chemical Sciences \\ Plymouth University \\ Plymouth \\ Devon PL4 8AA \\ *sbelt@plymouth.ac.uk
}

It is widely recognised that many science students benefit from industry-based experience during their undergraduate programmes ...

\begin{abstract}
This article presents and discusses the results of a project that focussed on identifying new work-based learning opportunities for chemistry students. Firstly, we investigated whether typical chemistry employers, who traditionally host sandwich or year-long placements, are able to offer short-term (e.g. summer) placements as an alternative work -based learning experience. Secondly, we determined to what extent non-traditional employers of chemistry graduates are also able to offer relevant and appropriate placement opportunities for chemistry students.

\section{Background}

It is widely recognised that many science students benefit from industry-based experience during their undergraduate programmes and that work-based learning helps to improve prospects of graduate employment ${ }^{1,2,3,4}$. Employer hosts also benefit from placements since they provide a 'first look' opportunity for potential recruitment and a tangible link into the development of undergraduate courses ${ }^{4,5}$. In chemistry, several universities have run placement schemes for a number of years, typically, as year-long sandwich programmes; these have proved to be highly beneficial to students and hosts $^{6,7}$. Despite the advantages of such schemes, the associated time and other resource commitments can prove unattractive to some student and employer hosts ${ }^{4}$.
\end{abstract}

We believed that relatively little (if any) previous work had been carried out, specifically, to investigate the possibility of offering short-term placements to chemistry students; either with traditional chemistry employers or with other potential employers of chemistry graduates (e.g. in engineering, medical, teaching communities, etc). We also felt that such placements could widen the opportunities for involvement by students and employers; thus, enhancing the employability of chemistry graduates and increasing the likely take-up of students onto chemistry courses in the first instance. Moreover, shortterm placements are likely to be more attractive to students and employers who have concerns about the financial and time commitments required by year-long placements.

Furthermore, non-traditional employers of chemists are probably underutilised in placement schemes, yet have the potential to offer excellent opportunities and, indeed, many chemistry students often go on to work in sectors other than mainstream chemistry ${ }^{8,9}$. By investigating perceptions to placement opportunities, the inclusion of this important sector into relevant placement schemes could be realised and would demonstrate any potential to extend into other non-traditional placement hosts.

\section{Methods}

A database of 182 companies was compiled from previous and existing placements, internal and external staff contacts, through the Royal Society of Chemistry (RSC) membership, the National Work Placement Fair at the Birmingham NEC (Oct 2011) and a local University Science \& Technology Careers Fair (Plymouth University, Nov 2011). A variety of science and non-science related industries were approached, including engineering, manufacturing, retail, legal, financial, IT, environmental and public sectors, in order to determine whether non-traditional chemistry employers are able to offer relevant and appropriate short- and long-term placement opportunities for chemistry students.

Companies were e-mailed with the aims and objectives of the study and asked to respond if they were interested in taking part. Based on general experience of e-mail surveys and the low response rate from a pilot survey, at least one follow-up telephone call was made to each recipient after about a week. 


\section{Employer consultation}

Open discussions were encouraged around an identified list of topics, designed to aid the development of short-term placements, going forward. A list of the main topics and some example discussion questions are summarised in Table 1. A summary report of each dialogue was written immediately following discussion interviews and attempts were made to keep responses within a set framework; however, due to the open nature of the consultations, not all areas were covered in detail and the extent depended on the relevance to the core business, time allowed and general interest.

\section{Main findings}

In total, 182 companies were identified and these were contacted, as described, over a period of about 6 months. As a result of initial and follow-up contact, 108 (59\%) companies responded either positively or negatively to taking part in the project, while $74(41 \%)$ did not respond at all. Those that did not respond were also deemed to be 'not interested'. 29 (16\%) companies provided feedback on the project objectives through face-to-face meetings (12), telephone discussions (11) and e-mail (6).

\section{Employer feedback $(n=29)$}

The findings from the employer interviews indicate that the overall perception of short-term placements is positive (17; $59 \%) .5(17 \%)$ companies stated that they had mixed feelings about placements; 1 (3\%) company stated that they did not see short-term placements positively, based on previous experience; and 6 did not have strong views, either way.

Only 2 (7\%) companies indicated that they had no experience of hosting students, with the remaining companies having previously hosted work-based learning opportunities to students in a variety of formats, including apprenticeships. 7 (24\%) companies, however, had no formal experience of assessment, feedback and monitoring of students for accreditation purposes; although, all companies confirmed that they understood and could accommodate the assessment requirements needed for undergraduate chemistry courses.

$18(62 \%)$ companies stated that they would prefer to take on students over the summer holidays, while only $3(10 \%)$ expressed a preference for a day release arrangement. Out of these 18 companies, 9 (31\%) specified that a minimum period of 6 - 8 weeks was needed for the company and/or student to benefit; while $5(17 \%)$ stated that a period of $10-12$ weeks was preferred to guarantee a return on the time invested. Only 1 (3\%) employer stated that 3 months was not sufficient time for students or their company to benefit from the experience and 7 did not indicate a preference, either way.

Table 1: Topics for discussion with employers and points for consideration.

\begin{tabular}{|c|c|}
\hline Perception: & $\begin{array}{l}\text { Perception of short-term placements - is it positive or negative? } \\
\text { Perception of students and their ability - what skills do they need to bring to placements? }\end{array}$ \\
\hline Experience: & $\begin{array}{l}\text { What is the previous experience with placements? } \\
\text { If no previous experience - why? } \\
\text { What would make the difference - e.g. University support? }\end{array}$ \\
\hline $\begin{array}{l}\text { Understanding /view of } \\
\text { short -term: }\end{array}$ & $\begin{array}{l}\text { Duration not set but between } 8 \text { weeks \& less than } 1 \text { year } \\
\text { Any preference for summer holiday or term time day release? } \\
\text { Must be sufficient time to work for } 40 \text { credits - ca. } 200 \text { hours }\end{array}$ \\
\hline Financial: & $\begin{array}{l}\text { Open to discussion and at employer's discretion? } \\
\text { Generally unpaid/voluntary? } \\
\text { Any possibility of a nominal stipend/travel costs/bonus? } \\
\text { Is there an expectation/need for funding to be provided to support the scheme? }\end{array}$ \\
\hline Benefits: & $\begin{array}{l}\text { What are the advantageous for the company, if any? } \\
\text { What are the advantageous for students, if any? }\end{array}$ \\
\hline $\begin{array}{l}\text { Barriers/limitations and } \\
\text { issues: }\end{array}$ & $\begin{array}{l}\text { For example: } \\
\text { Health \& safety requirements/Insurance to cover students/Contractual } \\
\text { Time \& cost to employer/student? } \\
\text { Choosing/application/vetting process of student. }\end{array}$ \\
\hline Potential Projects: & $\begin{array}{l}\text { Defining the boundaries? Is a spare pair of hands or a specific project needed? } \\
\text { What does the company need/want to achieve in this time? (this may help to define projects) }\end{array}$ \\
\hline $\begin{array}{l}\text { Commitment level } \\
\text { (perceived vs actual): }\end{array}$ & $\begin{array}{l}\text { Assessment contribution (e.g. feedback needed in order to grade for credits) } \\
\text { What are they prepared to do? (flexible approach) }\end{array}$ \\
\hline
\end{tabular}


In terms of the perceived benefits to the company, 10 (34\%) companies indicated that short-term placements could provide an opportunity to look for suitable graduate employees, while $10(34 \%)$ stated that placements could provide an extra resource (pair of hands) to free up staff to get on with other work or re-visit projects shelved due to time and work constraints. Other responses included:

- $\quad$ bringing 'young blood' into the company, with new and innovative ideas, whose fresh eyes and questioning nature can help motivate and encourage existing staff supporting further education by motivating and inspiring young people to continue their studies into higher education and give something back to the education system

- $\quad$ contributing to staff development of employees by exposing them to the training and mentoring of young people into the industry

- fulfilling a social responsibility to the community by encouraging young people into the science industry and supporting them at the start of their careers

$4(14 \%)$ companies stated that it was of no benefit to their company and 1 of these stated that it created more work. Employers thought that short-term placements could benefit students by bringing a 'real-life' work experience (12; 41\%) and/ or, more specifically, a science-related work experience (8; 28\%). 7 (24\%) companies thought that placements of any length should contribute towards students' employability and graduate employment prospects. The remaining responses included:

- $\quad$ career development, such as choosing a career field, for example, in education, a laboratory or consultancy

- $\quad$ to contribute to their education and broadening of minds

- $\quad$ focussing on transferrable skills; such as confidence, teamwork, and time and project management

These combined benefits to employers and students generally provided the main motivation for hosting placements.

Having made the decision to offer placements, however, employers stated that they expected students to arrive with a basic knowledge of scientific skills and technical understanding, including project, data and time management skills; literacy and numeracy; problem-solving skills and attention to detail and accuracy. In addition, employers also look for general employment skills, such as good communication, interpersonal skills, work ethic, common sense, enthusiasm and motivation. In contrast to the motivation for offering placements, the main reasons for not being interested in hosting short-term placements expressed by companies, included:

- $\quad$ only providing year-long placements

- a mismatch between employers' core business and students' subject area

- not providing placements at all (i.e. only take on graduates)

- $\quad$ the company being too small to accommodate students

- $\quad$ the summer duration too short to ensure a return on investment

- $\quad$ the economic climate means that workload and budgets are reduced
The main reason for lack of interest was that organisations only provided year-long placements and this was, generally, due to the length of time taken to train students to the required standards and/or a time/cost issue. Another significant reason for not hosting placements was that companies either required technical expertise in a specific subject area (e.g. engineering or hydrographics) or felt that they did not have any chemistryrelated aspects to their core business.

In terms of payment, 15 (52\%) companies stated that short-term placements would not be paid, although $8(28 \%)$ felt that a stipend, bonus or contribution towards travel may be considered. 4 (14\%) companies felt that unpaid placements may present limitations in the number of students wishing to take placements, as well as limiting the number of companies offering to host them, should the expectation of payment arise. 7 (24\%) companies indicated that other barriers may include external factors, such as security clearance, visa limitations and vaccinations, subject relevance to the core industry, workload and availability of suitable projects.

While the availability of suitable projects was felt to be a barrier, particularly for non-traditional chemistry employers considering chemistry students, $15(52 \%)$ companies suggested that the management of research and development (R\&D)/non-R\&D projects or data management and monitoring of routine analytical work had good potential as project themes.

\section{Traditional versus non-traditional employers and general} interest in hosting placements $(n=182)$ :

In addition to analysing the descriptive responses from the companies that took part in the feedback interviews, those companies that were interested in hosting chemistry students were categorised into traditional and non-traditional chemistry employers. Difficulties in defining industries into clear STEMrelated and non-STEM related employers has previously been reported $^{8}$ and, similarly, evaluating the types of industries into these two categories proved challenging.

It was decided that those businesses that included laboratory facilities and/or known chemistry affiliations, such as medical and public laboratories, food and pharmaceutical manufacturers, tertiary education science departments and the water industry, were considered as 'Traditional'; while those with no known association with chemistry, such as IT, retail, finance, and engineering, were considered as 'Non-traditional'; apart from those engineering firms allied to the environment, such as the water industry. It was recognised that these classifications were somewhat limited due to overlap between categories.

For the purposes of quantifying the data, 'Traditional' employers were further divided into Chemistry and Environmental, whilst 'Non-traditional' employers were sub-divided into Engineering (with the exception of those with environmental interests) and Other. A summary of the findings can be found in Table 2 . Whilst the majority of interested employers were from chemistry -related industries, as anticipated, it is clear that placement opportunities within non-traditional employers also exist. 


\section{Summary}

A number of key outcomes from this project can be identified. Firstly, we found that there was a reasonable level of interest expressed by employers to host short-term placements for chemistry students. Not surprisingly, the majority of interest came from chemistry-related industries; however, this study demonstrates that, there is also a level of interest in providing opportunities for chemistry students within other industries. Secondly, in terms of motivation, many employers view shortterm placements as an opportunity to assess a student for prospective graduate employment and/or as an extra pair of hands. The perceived benefits to students were found to be similar to those established previously for longer-term placements ${ }^{1,2,7}$, despite the relatively short duration. In contrast, the main reasons for employers not expressing an interest in hosting students on a short-term basis, was the lack of sufficient time available for training and, thus, a meaningful return on investment; plus the relevance of the degree discipline to company core business.

Thirdly, we found that the method of contact is essential to ensure success in projects that are relying on employers' feedback. Letters, e-mails and surveys alone, do not, generally, provide a meaningful response and, hence, follow-up in person is essential.

Finally, the results of this study have had a significant and positive impact on the importance and approach to short-term placements within Plymouth University's chemistry programme.

\section{Acknowledgements}

We would like to thank all the companies that took part in this study and provided feedback.

This activity was undertaken as a part of the National HE STEM Programme, via the South West Spoke. For more information on South West Spoke projects, please see $<w w w . h e s t e m-s w . o r g . u k>$

For more information on the overall national programme, please see

$<$ www.hestem.ac.uk>

\section{References}

1. Pegg, A., Waldock, J., Hendy-Isaac, S., Lawton, R. (2012). Pedagogy for employability. Higher Education Academy.

2. Lemanski, T., Mewis, R., Overton, T. (2011). An introduction to Work-Based Learning. A Physical Sciences Practice Guide. The Higher Education Academy UK Physical Sciences Centre. ISBN 978-1-903815-27-4.

3. Wallace, R., Murray, B., Overton, T. (2009). Effective Practice in Industrial Work Placement. A Physical Sciences Practice Guide. The Higher Education Academy UK Physical Sciences Centre. ISBN 978-1-903815-26-7.

4. Hogarth, T., Winterbotham, M., Hasluck, C., Carter, K., Daniel, W.W., Green, A.E., Morrison, J. (2007). Employer and University Engagement in the Use and Development of Graduate Level Skills. Main Report. Research Report RR835A. Department for Education and Skills (DfES)/IFF Research Ltd.

5. ASET (2007) Benefits of Placements. Available from: $<w w w$.asetonline.org/benefits.htm> [19 April 2012].

6. Gagan, M. (2009). Review of the student Learning Experience in Chemistry. Higher Education Academy Physical Science Centre. ISBN-978-1-903815-25-0. Available from:

$<$ www.heacademy.ac.uk/assets/ps/documents/ subject_reviews/chemrev_final.pdf> [19 April 2012].

7. Little, B. and Harvey, L. (2006). Learning through work placements and beyond. HECSU / Higher Education Academy's Work Placements Organisation Forum.

8. Mellors-Bourne, R., Connor, H., Jackson, C. (2011). STEM Graduates in non-STEM jobs. BIS research paper no.30. Careers Research \& Advisory Centre (CRAC) Ltd.

9. AGCAS/HECSU (2011) What do graduates do? Available from:

$<$ www.agcas.org.uk/agcas_resources/13-What-DoGraduates-Do> [19 April 2012].

Table 2: Employer groups and level of interest in hosting short-term chemistry placement students

\begin{tabular}{|c|c|c|c|c|c|c|c|}
\hline \multicolumn{2}{|l|}{ Industry: } & \multirow{2}{*}{$\begin{array}{c}\text { Number } \\
57\end{array}$} & \multirow{2}{*}{$\begin{array}{r}\% \text { (Total) } \\
31 \%\end{array}$} & \multicolumn{2}{|c|}{ Interested } & \multicolumn{2}{|c|}{ Not interested } \\
\hline \multirow{3}{*}{ Traditional } & Chemistry & & & 17 & $30 \%$ & 40 & $70 \%$ \\
\hline & Environmental & 30 & $17 \%$ & 6 & $20 \%$ & 24 & $80 \%$ \\
\hline & Subtotal & 87 & $48 \%$ & 23 & $26 \%$ & 64 & $74 \%$ \\
\hline \multirow{3}{*}{ Non-traditional } & Engineering & 47 & $25 \%$ & 1 & $2 \%$ & 46 & $98 \%$ \\
\hline & Other & 48 & $27 \%$ & 8 & $17 \%$ & 40 & $83 \%$ \\
\hline & Subtotal & 95 & $52 \%$ & 9 & $9 \%$ & 86 & $91 \%$ \\
\hline \multicolumn{2}{|l|}{ Overall } & 182 & $100 \%$ & 32 & $18 \%$ & 150 & $82 \%$ \\
\hline
\end{tabular}

